\title{
COMPARISON OF ELECTRICITY AND FOSSIL FUEL CONSUMPTION IN TROLLEYBUSES AND BUSES
}

\author{
Ivana Hurtova ${ }^{1}$, Marie Sejkorova ${ }^{1}$, Jan Verner ${ }^{1}$, Bronislav Sarkan ${ }^{2}$ \\ ${ }^{1}$ University of Pardubice, Czech Republic; ${ }^{2}$ University of Zilina, Slovakia \\ ivana.hurtova@upce.cz, branislav.sarkan@fpedas.uniza.sk
}

\begin{abstract}
In the paper there are results presented of yearlong testing of operation of a trolleybus Škoda $26 \mathrm{Tr}$ Solaris, which is equipped with energy storage lithium-titanate traction battery using nanocrystals (nLTO). The trolleybus has been in operation on routes of public transport in the city Zlín (Czech Republic) for more than one year. In addition, investigation in real operation for this kind of trolleybus, hybrid trolleybus equipped with a diesel generator and a bus regarding meeting the EURO 6 emissions standard with regard to electricity and diesel fuel consumption per $1 \mathrm{~km}$ was carried out. The experiment was carried out in the months with average outside temperature $-3.5^{\circ} \mathrm{C}, 18.7^{\circ} \mathrm{C}$, respectively.
\end{abstract}

Keywords: electric mobility, trolleybus, nano lithium-titanate battery.

\section{Introduction}

In view of the fact that transport is one of the industry sectors, which consume the most energy, therefore, the endeavour is increasing to find cost-effective, reliable and sustainable alternatives to conventional fuels $[1 ; 2]$. Electromobility is a generally prospective field and the field of electric buses is also a prospective sector. Virtually every major bus manufacturer develops or already produces a type of an electric bus. Increasing agglomeration requires high quality and environmentally friendly transportation, because electrobuses are one of the ways of future development. Currently, electrobuses are experiencing the biggest expansion in history [1]. In the last 5 years there was significant progress in improving the range of electric buses by innovations in the battery technology such as developing new ways of recharging and increasing capacity [3]. The advantages of electrobuses are environmentally friendly operation and low noise. The disadvantage is still the very high purchase price, which is an obstacle to the cost-effectiveness.

The last couple of decades have been an exciting time for the research in the field of Li-ion battery electrode materials. As new materials and strategies are found, Li-ion batteries will no doubt have an ever greater impact on our lives in the years to come [4]. Lithium-ion battery packs in hybrid and pure electric vehicles are always equipped with a battery management system (BMS). The BMS consists of hardware and software for battery management including, among others, algorithms determining battery states [5].

An electric train is currently one of the best solutions to urban passenger mobility challenges. However, diesel powered trains are still common in low capacity lines, on which the density of traffic is insufficient to justify the high fixed cost of railway electrification. In such cases, battery driven trams present an alternative [6]. The East Japan Railway Company developed a diesel and storage battery hybrid train to decrease the negative environmental impact and it has been in operation since 2007. The East Japan Railway Company Environmental Engineering Research Laboratory is now developing a "catenary and storage battery hybrid train system" [3].

The fleet of transport companies in Zlín (Czech Republic) operating public transport vehicles consists of buses and trolleybuses. In this paper, two variants of trolleybuses will be presented. The first variant will be a trolleybus with an auxiliary diesel generator. Another option is to replace the diesel generator with a properly designed Lithium titanium oxide $\left(\mathrm{Li}_{4} \mathrm{Ti}_{5} \mathrm{O}_{12}\right)$ using nanocrystals (nLTO) traction battery, which recharges the trolleybus from the overhead contact line. Both types of trolleybuses are used to drive to areas outside the overhead contact line.

In 2016, a 12-meter long trolleybus Škoda $26 \mathrm{Tr}$ was acquired for trial operation. It is driven by a Škoda asynchronous engine with the output of $160 \mathrm{~kW}$. An nLTO battery, with the capacity of $70 \mathrm{Ah}$ and the contracted guarantee of run of $12 \mathrm{~km}$, serves as energy storage. However, the real parameters reached during the on-road tests are better [7].

The nano lithium-titanate oxide battery is a rechargeable battery that is much faster to charge than other lithium-ion batteries [8]. It differs from other lithium-ion batteries because it uses lithiumtitanate oxide nanocrystal on the anode surface rather than carbon [6]. This gives the anode a surface 
area of about 100 square meters per gram, compared with 3 square meters per gram for carbon, allowing electrons to enter and leave the anode quickly [9]. This is advantageous because it does not create a SEI layer (Solid Electrolyte Interface), which acts as a barrier to the ingress and egress of Liion to and from the anode. This allows lithium-titanate batteries to be recharged more quickly and provide higher currents, when necessary [10]. A disadvantage of lithium-titanate batteries is that they have a lower inherent voltage $(2.4 \mathrm{~V})$, which leads to a lower specific energy of about $30-110 \mathrm{Wh} / \mathrm{kg}$ [8] than conventional lithium-ion battery technologies (which have an inherent voltage of $3.7 \mathrm{~V}$ ) [11]. Although the cells have a lower voltage and capacity than other lithium-ion battery technologies, the LTO chemistry compensates for that by offering a larger functional state of the charge range [11]. Table 1 shows the improvement of standard lithium-ion batteries over nano-titanate batteries.

Table 1

Improvement of standard lithium-ion batteries over nano-titanate batteries [12]

\begin{tabular}{|c|c|}
\hline Graphite material provides & Nano-Li titanate spinel material provides \\
\hline High reactivity with electrolyte & Low reactivity with electrolyte \\
\hline Forms resistive SEI layer & No resistive layer forms \\
\hline Two dimensional strained crystal lattice & Zero strain, 3D crystal lattice \\
\hline Limited Li-ion insertion rates & Stability and better kinetics \\
\hline Low surface area & High surface area \\
\hline Slow charge kinetics & Fast chargé kinetics \\
\hline SEI layer poisoning/decomposition & No SEI layer \\
\hline Limited thermal stability & Excellent thermal stability \\
\hline
\end{tabular}

The aim of this paper was comparison of direct cost of consumption of electricity energy and diesel fuel during operation of trolleybus Škoda $26 \mathrm{Tr}$, which is equipped with the electric motor and conveniently dimensioned traction battery (nLTO), too. The comparison was, in addition, carried out for the trolleybus Škoda $24 \mathrm{Tr}$, which is equipped with the electric motor and diesel engine and for the bus to meet the requirements of the emission standard EURO 6. The experiment was carried out in the months with average outside temperature $-3.5^{\circ} \mathrm{C}, 18.7^{\circ} \mathrm{C}$, respectively.

\section{Materials and methods}

The traction batteries are intended to drive the trolleybus Škoda $26 \mathrm{Tr}$ in the areas of the city without using the overhead line. They are designated for incorporation in the closed part of the bodywork. In the vehicle, there are 2 boxes of traction batteries connected in series using a battery distributor. One nLTO traction battery box is shown in Figure 1 and the complete set of traction batteries nLTO mounted in the vehicle - in Figure 2. Due to the large discharging and charging currents, lithium-ion batteries using nanotechnology on the anode surface were used, where lithiumtitanium oxide (nLTO) crystals were used instead of carbon. This significantly increases the area of the anode to approximately $100 \mathrm{~m}^{2} \cdot \mathrm{g}^{-1}$ compared to $3 \mathrm{~m}^{2} \cdot \mathrm{g}^{-1}$ for classic lithium-ion batteries with carbon anode. The disadvantage is, however, a significantly lower nominal voltage on individual cells. While carbon-powered batteries have a voltage of about 3.7 volts, the lithium-titanium batteries have only 2.4 volts.

The container contains the traction battery, which is composed of $14 \mathrm{nLTO}$ battery modules and 14 monitoring units. Traction batteries are placed on coolers, by which performance losses are taken away, caused by the performance demands on the traction battery due to the operation of the vehicle [12].

The traction battery is designed for 15 driving cycles of $8 \mathrm{~km}$ each per day subject to full load of the vehicle, when driving on plain road in urban traffic. In this, $30 \%$ output of heating and full output of air conditioning in the passenger space and full output of heating in the driver's cab are considered. Within each cycle, the ratio of driving under the overhead line to driving on the traction battery 2:1 is observed. The operation is noiseless and emission-free, with the absence of an internal combustion engine. The trolleybuses are designed for possible trolleybus operation in case the traction batteries are dismounted [13]. 


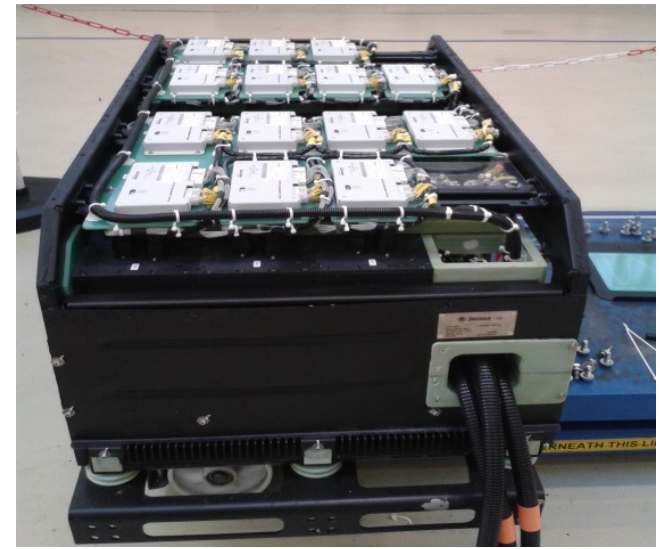

Fig. 1. Traction battery container

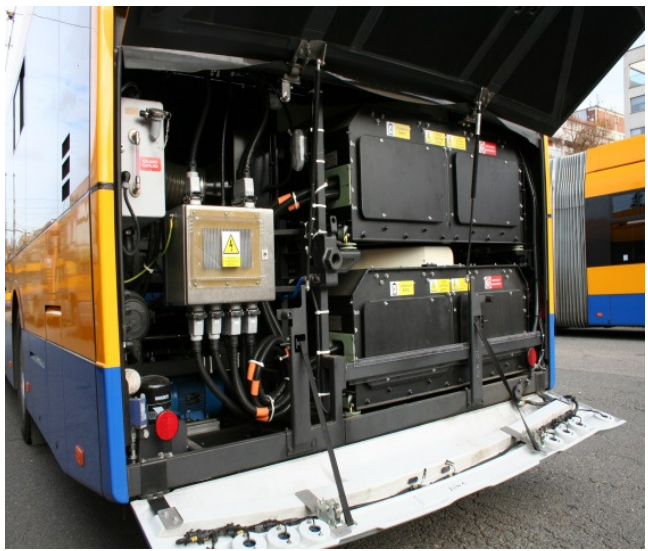

Fig. 2. Complete set of traction batteries nLTO mounted in vehicle

Table 2 below presents a technical description of the two variants of the trolleybuses listed in this paper, the trolleybus Škoda $26 \mathrm{Tr}$ equipped with nLTO traction batteries and the trolleybus Škoda 24 Tr with an auxiliary diesel generator, which output is $100 \mathrm{~kW}$.

Both types of trolleybuses are used not only for driving under the overhead contact line. But they are also used in areas, where the overhead contact line is not installed.

Table 2

Description of trolleybus Škoda 26 Tr equipped with nLTO traction batteries and trolleybus Škoda $24 \mathrm{Tr}$ equipped with a diesel generator

\begin{tabular}{|c|c|c|}
\hline Parameter & $\begin{array}{c}\text { Trolleybus Škoda 26 Tr } \\
\text { equipped with nLTO traction } \\
\text { batteries }\end{array}$ & $\begin{array}{c}\text { Trolleybus Škoda 24 Tr } \\
\text { equipped with a diesel } \\
\text { generator }\end{array}$ \\
\hline Manufactured & Škoda Electric 2016 & Škoda Electric 2014 \\
\hline Rated power & $160 \mathrm{~kW}$, running on $600 \mathrm{~V}$ & $210 \mathrm{~kW}$, running on $600 \mathrm{~V}$ \\
\hline Total capacity & 80 passengers & 86 passengers \\
\hline Maximum speed & $65 \mathrm{~km} \cdot \mathrm{h}^{-1}$ & $65 \mathrm{~km} \cdot \mathrm{h}^{-1}$ \\
\hline Empty vehicle weight & $12820 \mathrm{~kg}$ & $12800 \mathrm{~kg}$ \\
\hline Vehicle width & $2.55 \mathrm{~m}$ & $12.50 \mathrm{~m}$ \\
\hline Vehicle length & $12 \mathrm{~m}$ & $12 \mathrm{~m}$ \\
\hline Air condition & $\begin{array}{c}\text { For the driver and in the } \\
\text { passenger salon }\end{array}$ & Only in the driver's cabin \\
\hline
\end{tabular}

The bus EURO 6 emission standard, which is part of the real-life evaluation of this post, was acquired in 2016. The vehicle is powered by a Cursor 9 engine that has a power output of $265 \mathrm{~kW}$. The length of the bus is $12 \mathrm{~m}$ and it includes air conditioning in the driver's cab and also in the lounge area for travel.

For comparison of direct cost operation of trolleybuses and buses with the EURO 6 emission standard information is used from the tachograph TT-62, which is installed in all inspected vehicles. Direct cost operation includes consumption of traction energy and fuel during ordinary daily operation with passengers on the board of the vehicles. For experiment purposes the loss of energy in transformer stations and in the overhead contact line was not considered. The operational cost was determined in EUR per $\mathrm{km}$ for each transport means in the month with average temperature $-3.5^{\circ} \mathrm{C}$ and for the month with an average temperature $18.7^{\circ} \mathrm{C}$. The operational cost was the expression as a percentage part of the total cost.

\section{Results and discussion}

Table 3 shows the average fuel and electricity consumption of urban public transport vehicles described in this paper, which was generated in real operation within one month with an average outdoor temperature of $-3.5^{\circ} \mathrm{C}$ and one month with an average temperature of $18.7^{\circ} \mathrm{C}$. 
For the trolleybus Škoda $24 \mathrm{Tr}$ with an auxiliary diesel generator, total consumption was divided into diesel and electricity consumption. The trolleybus with nLTO traction batteries includes total power consumption only and a diesel fuel consumption of the bus. In the aforementioned vehicles the heating in the passenger compartment and the driver's cabin was switched on as needed.

The average consumption needed for $1 \mathrm{~km}$ of real driving operation of trolleybuses Škoda $26 \mathrm{Tr}$ with nLTO traction batteries, Škoda 24 Tr with a diesel generator and a EURO 6 bus

\begin{tabular}{|c|c|c|}
\hline Vehicle & $\begin{array}{c}\text { Average consumption } \\
\text { with average outside } \\
\text { temperature of } \mathbf{- 3 . 5}{ }^{\circ} \mathbf{C}\end{array}$ & $\begin{array}{c}\text { Average consumption } \\
\text { with average outside } \\
\text { temperature of } 18.7^{\circ} \mathbf{C}\end{array}$ \\
\hline Trolleybus with an auxiliary diesel generator & $73.41 \cdot(100 \mathrm{~km})^{-1}$ & $46.11 \cdot(100 \mathrm{~km})^{-1}$ \\
\cline { 2 - 3 } & $2.52 \mathrm{kWh} \cdot \mathrm{km}^{-1}$ & $1.7 \mathrm{kWh} \cdot \mathrm{km}^{-1}$ \\
\hline Trolleybus with nLTO traction batteries & $2.37 \mathrm{kWh} \cdot \mathrm{km}^{-1}$ & $1.5 \mathrm{kWh} \cdot \mathrm{km}^{-1}$ \\
\hline EURO 6 bus diesel & $44.31 \cdot(100 \mathrm{~km})^{-1}$ & $39.11 \cdot(100 \mathrm{~km})^{-1}$ \\
\hline
\end{tabular}

From a table with a 2-month consumption with different outside temperatures, it can be stated that the best results were achieved by the trolleybus $26 \mathrm{Tr}$ with nLTO traction batteries and the EURO 6 emission standard bus compared to the trolleybus $24 \mathrm{Tr}$ with built-in diesel generator depending on the type of drive.

The direct cost operation is shown in Figures 3 and 4 in percentages with different average outside temperatures. Values were obtained from results of average fuel consumption for each type of vehicle. For the bus fitted with the diesel engine and for the trolleybus Škoda $24 \mathrm{Tr}$ with the diesel generator fuel consumption was expressed in liter per one kilometer. For the trolleybus Škoda 26 Tr equipped with the traction battery nLTO and for the trolleybus $24 \mathrm{Tr}$ the energy was used from the overhead contact line and fuel consumption was expressed in $\mathrm{kWh}$ per one kilometer. The results of consumption of all vehicles were multiplied direct cost in EUR per $1 \mathrm{~km}$. The purchase price was 0.08 EUR per $1 \mathrm{kWh}$ for electric energy and 0.82 EUR per 1 liter of diesel. Operation cost is expressed in percentage. Total operation cost $(100 \%)$ results per 2 considered months.

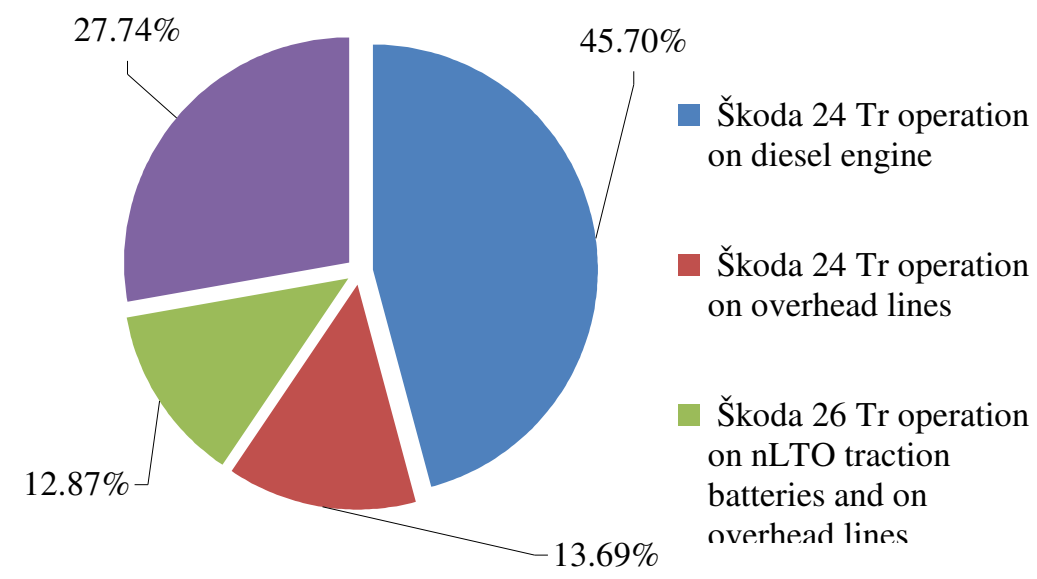

Fig. 3. Direct operating costs in $\%$ per $1 \mathrm{~km}$ arising in real operation in month with average outside temperature of $-3.5^{\circ} \mathrm{C}$ of trolleybuses Škoda $26 \mathrm{Tr}$ with nLTO traction batteries, ک̌ koda $24 \mathrm{Tr}$ with diesel generator and EURO 6 bus

The trolleybus equipped with the diesel generator had the operation cost $45.70 \%$ in the month with average temperature $-3.5^{\circ} \mathrm{C}$. The bus EURO 6 had the operation cost $27.74 \%$. The lowest operating costs at the level of $12.87 \%$ were for the trolleybus with nLTO traction batteries. A similar development was investigated in the month with an average temperature $18.7^{\circ} \mathrm{C}$. The highest operation costs with $40.76 \%$ were found for the trolleybus with the diesel aggregate and the best results with $11.53 \%$ were for the trolleybus using traction batteries. The bus achieved $34.64 \%$ in comparison with the results of the operation cost of the trolleybus. The results from testing the trolleybus with the traction battery are comparable with the conclusion of the paper [14]. The authors 
of the mentioned paper carried out the experiment with the same type of trolleybus in a period from 2011 to 2015 in Landskrona, Sweden. The energy consumed was $1.1 \mathrm{kWh} / \mathrm{km}$. It can be stated that the operation on the routes used traction energy from the overhead contact line and on part of the routes running out of the overhead contact line the best result was achieved by the trolleybus using the traction batteries nLTO.

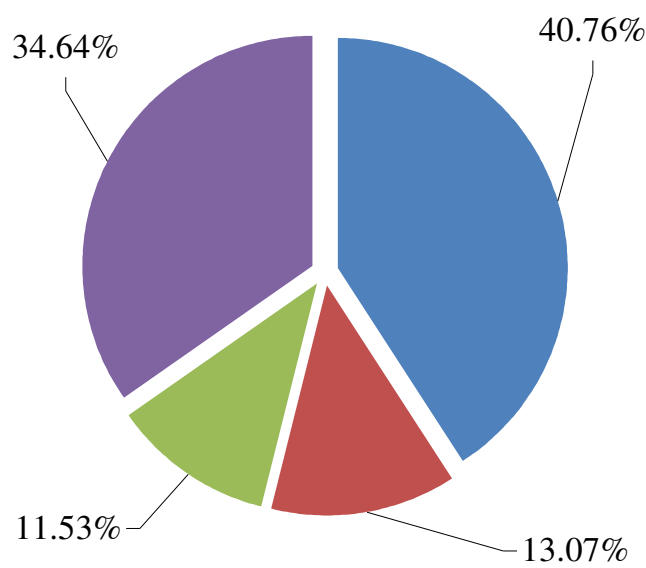

Škoda 24 Tr operation on diesel engine

Škoda 24 Tr operation on overhead lines

Škoda 26 Tr operation on nLTO traction batteries and on overhead lines

Fig. 4. Direct operating costs in \% per $1 \mathrm{~km}$ arising in real operation in month with average outside temperature of $18.7^{\circ} \mathrm{C}$ of trolleybuses Škoda $26 \mathrm{Tr}$ with nLTO traction batteries, Škoda $24 \mathrm{Tr}$ with diesel generator and EURO 6 bus

\section{Maintenance of the trolleybus with nLTO traction batteries}

Maintenance of the trolleybus with nLTO traction batteries does not change substantially from the maintenance of trolleybuses of the same type without mounted traction batteries. The service of the vehicles is ensured by regular tours of 10 thousand $\mathrm{km}$ and after regular 30 ths. $\mathrm{km}$ up to $120 \mathrm{~km}$ or 2 years.

Guaranteed nLTO battery life is 7 years. As the trolleybus with nLTO traction batteries is first operated in the Czech Republic with conditions typical of this country, the maintenance operations may vary slightly. Against trolleybuses with auxiliary diesel generator, there is a big advantage in the maintenance of the traction drive itself, which consists of checking battery cleanliness, tightening connections, checking capacity and cooling control.

\section{Conclusions}

The aim of this paper is to compare the direct costs of consumed electricity and diesel. These costs were generated by the operation of the trolleybus Škoda $26 \mathrm{Tr}$ equipped with nLTO traction batteries, the trolleybus Škoda $24 \mathrm{Tr}$ equipped with a diesel generator and a bus EURO 6 emission standards in the month with an average temperature of $-3.5^{\circ} \mathrm{C}$ and in the month with an average temperature of $18.7^{\circ} \mathrm{C}$.

- After comparing the total consumption of the presented public transport vehicles in this contribution and the direct operating costs in two months with different average outdoor temperatures, it can be stated that the trolleybus operation with built-in traction batteries with the new nano lithium-titanate battery (nLTO) is significantly cheaper and thus also much more economical. On the other hand, the results of a trolleybus with a built-in auxiliary diesel generator showed the highest consumption and, therefore, the highest operating costs compared to other vehicles. After the bus evaluation of the EURO 6 emission standard in real operation and in comparison with the trolleybuses of the two variants, it can be stated that it provides good conditions in terms of economic traffic in urban transport.

- The study presented in this paper points to the advantage of the concept of a vehicle with nLTO traction batteries, wherever an existing overhead contact line is already available. 


\section{Acknowledgements}

This study is funded by the University of Pardubice (No. SGS_2018_023).

\section{References}

[1] Mwambeleko J. J. etc. Tram and Trolleybus Net Traction Energy Consumption Compariso. Proceedings of 18th International Conference on Electrical Machines and Systems (ICEMS2015), 25-28 October 2015, Pattaya, Thailand, pp. 1-5.

[2] Barrero R., Mierlo J. V., Tackoen X. Energy savings in Public Transport. IEEE Vehicular Technology Magazine, vol. 3, no. 3, 2008, pp. 26-36.

[3] Mwambeleko J. J., Kulworawanichpong T. Battery and accelerating-catenary hybrid system for rail vehicles and trams. Proceedings of 2017 International Electrical Engineering Congress (iEECON), 8-10 March 2017, Pattaya, Thailand, pp. 1-4.

[4] Nitta N., Wu F., Lee J. T., Yushin G.. Li-ion battery materials: present and future. Materials Today, vol. 18, no. 5, 2015, pp. 252-264.

[5] Waag W., Fleischer Ch., Sauer D. U. Critical review of the methods for monitoring of lithium-ion batteries in electric and hybrid vehicles. Journal of Power Sources, vol. 258, 2014, pp. 321-339.

[6] Mwambeleko J. J., Kulworawanichpong T. Battery electric multiple units to replace diesel commuter trains serving short and idle routes. Journal of Energy Storage, vol. 11, 2017, pp. 7-15.

[7] Hurtová I., Sejkorová M. Experience with the Operation of a Partial Trolleybus. Proceedings of International conference "CMDTUR 2016”, October 2016, Žilina, Slovakia, pp. 100-112.

[8] Cowie I., Chief E., Vision M. All About Batteries, Part 12: Lithium Titanate (LTO). EETimes. [online] [15.01.2018].

Available at:http://www.eetimes.com/author.asp?section_id $=36 \& d o c \_i d=1325358$.

[9] Graham-Rowe D. Charge a battery in just six minutes. NewScientist. [online] [09.02.2018]. Available at: https://www.newscientist.com/article/dn7081-charge-a-battery-in-just-six-minutes/.

[10]5 Benefits of Lithium Titanate Batteries. [online] [28.12.2017]. Available at: http://www.tiankangbattery.com/5-benefits-of-lithium-titanate-batteries.

[11] Toshiba Developing 3.0 Ah High Power SCiB Li-Ion Cell for HEV Applications. Green Car Congress. [online] [17.01.2018]. Available at: http://www.greencarcongress.com/2008/05/toshiba-develop.html.

[12] Brunell M. Lithium Titanate Battery Modelling and Predicting Aged Performance. WMG, University of Warwick. [online] [28.12.2017]. Available at: https://www2.warwick.ac.uk/fac/sci/wmg/research/hvmcatapult/research/posters/lithium_titanate_ battery_modelling_and_predicting_aged_performance_by_michael_brunell.pdf.

[13] Škoda Electric. Technical specifications. Technical description TBS 4.1: Škoda Electric 2016, [In Czech]

[14] Projekt Slide In: parciální trolejbus střídá trolejbusové a autobusové linky [online] [28.04.2018]. Available at: http://www.proelektrotechniky.cz/elektromobilita/146.php 